\title{
The Antioxidant and Antimicrobial Capacities of Phenolic Profiles of Some Salvia L. Seeds Grown in Turkey
}

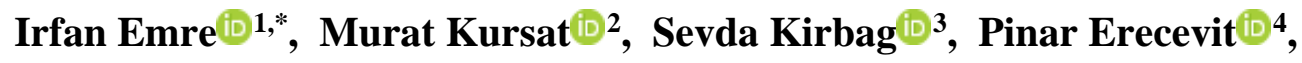 \\ Mustafa Yunus Emre ${ }^{(i)}{ }^{5}$, Okkes Yilmaz ${ }^{(13}$, Semsettin Civelek ${ }^{(i)} 3$
}

\author{
${ }^{1}$ Department of Basic Education, Faculty of Education, Firat University, Elazığ, Turkey \\ ${ }^{2}$ Department of Biology, Faculty of Science and Arts, Bitlis Eren University, Bitlis, Turkey

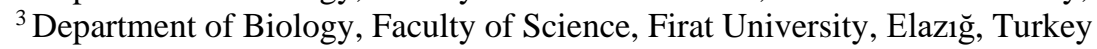 \\ ${ }^{4}$ Department of Food Processing, Pertek Vocational Higher School, Munzur University, Tunceli, Turkey \\ ${ }^{5}$ Department of Medical Services and Techniques, Vocational Higher School of Health Services, Mardin Artuklu \\ University, Mardin, Turkey
}

\begin{abstract}
The aim of current study is to show phenolics, antioxidant capacities and antimicrobial activities of seeds of five Salvia L. (S. frigida Boiss., $S$. candidissima subsp. candidissima Vahl., S. virgata Jacq., S. verticillata L. var. verticillata and $S$. russellii Benth.) taxa grown in Turkey. The flavonoid and phenolic acid contents were measured by using HPLC whilst the antioxidant capacities were determined by using different methods. In addition, agar well diffusion method was used to determine the antimicrobial activities of Salvia species in this study. It was found that $S$. frigida, S. verticillata var. verticillata and $S$. russellii have the highest catechin contents and S. frigida and $S$. verticillata var. verticillata have high rosmarinic acid while $S$. frigida, $S$. candidissima subsp. candidissima and $S$. verticillata var. verticillata have high vanilic acid. Also, it was determined that $S$. frigida and $S$. verticillata var. verticillata have high DPPH radical scavenging activities in 150 and $250 \mu \mathrm{L}$ while $S$. frigida and $S$. verticillata var. verticillata have highest ABTS radical scavenging activity in all concentrations apart from $25 \mu \mathrm{L}$ for $S$. frigida. Furthermore, S. frigida and S. verticillata var. verticillata have high total phenolic contents. On the other hand, Salvia species have similar lipid peroxidation inhibitions. However, the metal chelating activities of Salvia species are different. And also, it was demonstrated that Salvia taxa have antimicrobial activity.
\end{abstract}

\section{ARTICLE HISTORY}

Received: August 13, 2020

Revised: October 10, 2020

Accepted: March 05, 2021

\section{KEYWORDS}

Antimicrobial activity, Antioxidant capacity,

Flavonoids,

Phenolic acids,

Salvia L.

\section{INTRODUCTION}

Herbs from the Lamiaceae have been used in traditional medicine for more than 2000 years to treat different diseases such as cancer, diabetes, depression, memory enhancement and infection throughout the world (Shekarchi et al., 2012; Lopresti, 2017). Lamiaceae, contains most popular aromatic plants including marjoram, sage, basil and thyme, have strong antioxidant and antimicrobial activity due to rich in biologically effective components as caffeic

CONTACT: İrfan Emre $\square$ irfanemre@gmail.com Department of Basic Education, Faculty of Education, Firat University, Elazı̆̆ Turkey 
acid, rosmarinic acid, carvacrol and thymol (Hossain et al., 2010; Khaled-Khodjaa et al., 2014; Skendi et al., 2017). And also, Turkey is accepted as a significant gene center for the Lamiaceae which is represented by 45 genera, 565 species and 735 taxa in Turkey (Dorman et al., 2004; Cetin et al., 2006).

Salvia, is the from subfamily Nepetoideae of the Mentheae tribe of the Lamiaceae, which includes 1000 taxa spread out in the different regions of the world (Kahraman, Celep \& Dogan, 2009). The name of Salvia is originated from Latin "salvare" or "salvus" and is meaning healing due to using folk medicine (Fotovvat et al., 2019). Many Salvia species are rich in polyphenol and terpenes and are used as digestive, antiinflammatory, antiseptic, and antioxidant agents (Dent et al., 2017; Gregorczyk-Karolak \& Kiss, 2018). Phenolic compounds are in charge of antioxidant capacity in the sage and rosmarinic acid, caffeic acid, chlorogenic acid, vanillic acid, salvianolic acid, luteolin and apigenin are major phenolics in sage (Jasicka-Misiak et al., 2018; Vergine et al., 2019; Katanic-Stankovica et al., 2020).

The genus is represented by 89 species and 95 taxa in flora of Turkey and the endemism of the genus is $45 \%$ in Turkey (Kahraman et al., 2018). Generally, the studies about the determination of antioxidant and antimicrobial capacities of sage is related to plant extracts and there are lack of antioxidant capacities in sage seeds. And also the antimicrobial studies is related to plant extracts not seeds. The goal of the current study is to determine phenolic compounds antioxidant capacities and antimicrobial activities of phenolics of seeds in five Salvia L. (S. frigida Boiss., S. candidissima Vahl subsp. candidissima, S. virgata Jacq., S. verticillata L. subsp. verticillata., S. russellii Bentham) taxa grown in Turkey.

\section{MATERIAL and METHODS}

The plants were collected from natural habitats. The plant samples and seeds were deposited in Firat University Herbarium (FUH). The localities of studied Salvia L. taxa were given in Table 1 .

Table 1. Localities of studied Salvia L. Taxa.

\begin{tabular}{ll}
\hline \multicolumn{1}{c}{ Taxa } & \multicolumn{1}{c}{ Locality } \\
\hline Salvia frigida Boiss. & Elazig Baskil district, Hacı Mustafa Village, $1850 \mathrm{~m}$ \\
Salvia candidissima Vahl subsp. candidissima & Elazig Baskil district, Hacı Mustafa Village, $1750 \mathrm{~m}$ \\
Salvia virgata Jacq. & Elazig Baskil district, Bolucuk Village, $1500 \mathrm{~m}$ \\
Salvia verticillata L. subsp. verticillata & Elazig Baskil district, Bolucuk Village, $1490 \mathrm{~m}$ \\
Salvia russellii Bentham & Elazig Baskil district, Quercus forest around, $1400 \mathrm{~m}$ \\
\hline
\end{tabular}

\subsection{Microbial Strain}

In this study, fungi (Candida albicans FMC 17 and Candida glabrata ATCC 66032), dermatophyte (Trichophyton sp., Epidermophyton sp.) and bacteria [(Escherichia coli (ATCC 25922), Klebsiella pneumoniae (FMC 5), Staphylococcus aureus (COWAN 1), Bacillus megaterium (DSM 32)] were used to evaluate the antimicrobial activities of studied Salvia taxa.

\subsection{Extraction Protocol of Phenolics}

PREVAIL C18 reversed-phase column $(15 \times 4.6 \mathrm{~mm}, 5 \mu \mathrm{m}$, USA) was used and methanol/acetonitrile/water (46/8/46, v/v/v) comprising $1.0 \%$ acetic acid is mobile phase ( $\mathrm{Zu}$, $\mathrm{Li}, \mathrm{Fu} \& \mathrm{Zhao}, 2006)$. Morin, kaempferol, naringenin, quercetin, catechin, naringin, resveratrol, myricetin, rutin and vanillic acid, ferulic acid, rosmarinic acid, cinnamic acid, and caffeic acid were determined. $1.0 \mathrm{~mL} / \mathrm{min}$ was used as flow rate and $10 \mu \mathrm{L}$ samples were given as injection volume. Chromatographic conditions were performed at $25^{\circ} \mathrm{C}$. 


\subsection{DPPH Radical Scavenging Activity}

$25,50,100,150$ and $250 \mu \mathrm{L}$ of extracts were treated with $25 \mathrm{mg} / \mathrm{L} \mathrm{DPPH}$ solved in methanol $(4.0 \mathrm{~mL})$. The DPPH radical protocol was performed based on Liyana-Pathiranan and Shahidi (2005)'s method in the current study. The absorbances were measured at $517 \mathrm{~nm}$ after the samples were stored in the dark for 30 minutes. $1 \mu \mathrm{M}$ quercetin was used as reference. The formula (1) was used for the DPPH radical scavenging potential is following:

$$
\% \text { inhibition }=\frac{\mathrm{Ab}(\text { control })-\mathrm{Ab}(\text { sample })}{\mathrm{Ab}(\text { control })} \times 100
$$

The absorbance of control was represented as $\mathrm{Ab}$ (control) and the absorbance of sample was represented as $\mathrm{Ab}$ (sample).

\subsection{ABTS Radical Scavenging Activity}

ABTS [2,2-azinobis-(3-ethylbenzothiazoline-6-sulfonic acid) diammonium salt] assay was determined according to the Ree et al. (1999) methods. $7 \mathrm{mM}$ ABTS and $2.45 \mathrm{mM}$ potassium persulphate were mixed to form $\mathrm{ABTS}^{\circ+}$ solution. The solution was stored at room temperature approximately $12-16 \mathrm{~h}$. And ABTS was dissolved with water to provide an absorbance of $0.700 \pm 0.020$. Lastly, three $\mathrm{mL}$ of diluted ABTS were mixed with 25, 50, 100, 150 and $250 \mu \mathrm{L}$ of extract and absorption was determined in the 6 min at $734 \mathrm{~nm}$ (Skotti et al., 2014). The formula was used for the DPPH radical scavenging potential is following (2):

$$
\% \text { inhibition }=\frac{\mathrm{Ab}(\text { control })-\mathrm{Ab}(\text { sample })}{\mathrm{Ab}(\text { control })} \times 100
$$

The absorbance of control was represented as $\mathrm{Ab}$ (control) and the absorbance of sample was represented as $\mathrm{Ab}$ (sample).

\subsection{Determination of Total Phenolics}

Folin-Ciocalteu method was used to evaluate total phenolics (Singleton et al., 1999). 100 $\mu \mathrm{L}$ extracts were mixed with $3.16 \mathrm{~mL}$ of $\mathrm{H}_{2} \mathrm{O}$ and $200 \mu \mathrm{L}$ of Folin-Ciocalteu solution. The samples were stored at room temperature about $3 \mathrm{~min}$. Later, the extracts were treated with anhydrous sodium carbonate $(20 \% \mathrm{w} / \mathrm{v})$ and total phenolic content was observed at $765 \mathrm{~nm}$ after two hours in room temperature (Robya et al., 2013). The total phenolic amount was evaluated by using gallic acid equivalents ( $\mu \mathrm{gGAE} / \mathrm{mg})$.

\subsection{Chelating Effects of Ferrous Ions}

The chelating activities of samples were evaluated method by Dinis et al. (1994). $50 \mu \mathrm{L}$ of $2 \mathrm{mM} \mathrm{FeCl} 2$ was injected to extracts $(50,100,250$ and $500 \mu \mathrm{g} / \mathrm{mL}) .5 \mathrm{mM}$ ferrozine $(0.2$ $\mathrm{mL}$ ) mixed with extracts to start the reaction. The extracts were shaken vigorously and stored at room temperature approximately $10 \mathrm{~min}$. The absorbances of samples were measured at 562 $\mathrm{nm}$. The inhibition (\%) of ferrozine-Fe ${ }^{2+}$ complex was evaluated based on following formula (3):

$$
\% \text { Chelating activity }=\left[1-\left(\frac{\mathrm{Abs}}{\mathrm{Abc}}\right)\right] \times 100
$$

The absorbance of sample was represented as Abs and the absorbance of control was represented as Abc where 100 where $\mathrm{Na} 2 \mathrm{EDTA}$ was used as positive control.

\subsection{Antioxidant Activity against TBARS}

The antioxidant activity of samples was measured according to Shimoi et al. (1994)' method. The samples were prepared by using DMSO (dimethyl sulfoxide). The $\mathrm{Fe}^{2+}$ $\left(\mathrm{FeCl}_{2} .2 \mathrm{H}_{2} \mathrm{O}\right)$ and hydrogen peroxide were used in the experiments. Also, oleic acid $(3.35 \mathrm{mM})$, linoleic acid $(9.01 \mathrm{mM})$ and linolenic acid $(2.30 \mathrm{mM})$ were used dissolved in DMSO. Sage 
extracts, control and Fenton reagent groups were formed. The control group contained $0.5 \mathrm{~mL}$ of fatty acid and a buffer ( $\mathrm{pH}=7.4 ; 0.05 \mathrm{M}$ Tris $\mathrm{HCl} ; 0.2 \%$ Tween, 20; $0.15 \mathrm{M} \mathrm{KCl})$ whilst the fenton group contained buffer; hydrogen peroxide $(0.01 \mathrm{mM}) ; 0.5 \mathrm{~mL}$ of fatty acid and $\mathrm{FeCl}_{2} .2 \mathrm{H}_{2} \mathrm{O}(50 \mu \mathrm{M})$ and the extracts comprised $\mathrm{FeCl}_{2}(50 \mu \mathrm{M}), 0.25 \mathrm{~mL}$ sage extract, $0.5 \mathrm{~mL}$ of fatty acid and hydrogen peroxide $(0.01 \mathrm{mM}) .0 .1 \mathrm{~mL}$ of a $4 \%(\mathrm{w} / \mathrm{v})$ BHT was added to all groups to protect the more oxidation and the examples were stored at the $37^{\circ} \mathrm{C}$ approximately $24 \mathrm{~h}$. After that, $1 \mathrm{~mL}$ of samples from three groups was taken and treated with $1 \mathrm{~mL}$ of $0.6 \%$ TBA and the samples were stored at $90{ }^{\circ} \mathrm{C}$ for $30 \mathrm{~min}$. Finally, $4 \mathrm{~mL}$ butan-1-ol was injected to tubes, blended and centrifuged at $4250 \mathrm{rpm}$ for $10 \mathrm{~min}$. The absorbance of the supernatant was measured at $532 \mathrm{~nm}$. MDA standard curves were formed by 1,1,3,3-tetramethoxypropane, and TBARS were written as mg MDA/kg dry matter (Keser et al., 2014).

\subsection{Antimicrobial Activity}

Antimicrobial activities were evaluated agar well diffusion method according to Collins and Lyne (1987)' method. Agar contained Sabouroud Dextrose Agar (Oxoid), Mueller Hinton Agar (Difco) and Malt Extract Agar (Difco) and McFarland standard. And also, bacteria (10 cells $/ \mathrm{mL})$, dermatopyhte and yeast $\left(10^{4}\right.$ cells $\left./ \mathrm{mL}\right)$, were found in $100 \mu \mathrm{L}$ suspension. Phenolics $(10 \mu \mathrm{L})$ were added to the well after the wells were filled with cork-borer $(0.85 \mathrm{~cm})$ and plates. After that, incubation for bacteria was conducted at $37 \pm 0.1^{\circ} \mathrm{C}$ for $24 \mathrm{~h}$ and for yeast and dermatophyta fungi were conducted at $25 \pm 0.1^{\circ} \mathrm{C}$ for $72 \mathrm{~h}$. The inhibiton zone was referenced to decide the antimicrobial activity.

\subsection{Statistical Analysis}

All analysis were performed by using SPSS 21.0 packet program. The simple lineer regression model was used to found the correlation between antioxidant capacity (ABTS, DPPH and metal chelating) and total phenolic contents. Data obtained from present study represented as mean values \pm standard deviation. Also, to evaluate the significance of the observed differences, the least significant difference (LSD) test was used in the antimicrobial activity. The conclusions were expressed as mean \pm S.D. $p<0.0001, p<0.001$ and $p>0.05$ have been conceived significant when compared to the control group (ampicillin sulbactam, mycostatin). All samples were analysed in triplicate.

\section{RESULTS and DISCUSSION}

Present study showed that myricetin, morin, quercetin, kaempferol, naringenin and resveratrol are low or absent (Table 2). S. verticillata subsp. verticillata has the highest rutin (114.47 $\pm 1.25 \mu \mathrm{g} / \mathrm{mg})$, catechin $(583.79 \pm 1.27 \mu \mathrm{g} / \mathrm{mg})$ and naringin $(128.8 \pm 1.57 \mu \mathrm{g} / \mathrm{mg})$ contents. In addition, it was demonstrated that $S$. frigida $(107.77 \pm 2.37 \mu \mathrm{g} / \mathrm{mg})$ and S. russellii $(306.88 \pm 1.54 \mu \mathrm{g} / \mathrm{mg})$ have catechin content. And also, this study demonstrated that naringin contents of $S$. candidissima subsp. candidissima and $S$. virgata are low $(9.27 \pm 0.81-9.17 \pm 0.57$ $\mu \mathrm{g} / \mathrm{mg}$ ) (Table 2). Literature determined that Salvia posses ferulic acid, caffeic acid, chlorogenic acid, o-coumaric acid, p-OH-benzoic acid, protocatechinic acids, rosmarinic acid, apigenin, luteolin, kaempferol and quercetin (Kupeli Akkol et al., 2008; Hamrouni-Sellami et al., 2013; Dincer et al., 2012; Alcantaraa et al., 2019). Similarly, this study showed that studied Salvia seeds have vanillic acid, caffeic acid, ferulic acid and rosmarinic acid (Table 2). Whereas, it has been showed that cinnamic acid contents of studied Salvia seeds absent or low (Table 2). On the other hand, present study demonstrated that $S$. frigida $(16.32 \pm 0.85 \mu \mathrm{g} / \mathrm{mg})$ and $S$. candidissima subsp. candidissima $(28.57 \pm 1.14 \mu \mathrm{g} / \mathrm{mg})$ posses relatively high ferulic acid content compared to other studied Salvia taxa in this study (Table 2). And also, this study found that Salvia verticillata subsp. verticillata $(152.79 \pm 1.33 \mu \mathrm{g} / \mathrm{mg})$, S. frigida $(107.38 \pm 1.51$ $\mu \mathrm{g} / \mathrm{mg}$ ), S. virgata $(88.24 \pm 0.75 \mu \mathrm{g} / \mathrm{mg}$ ) have high rosmarinic acid amounts (Table 2). Zengin et al. (2018) found that rosmarinic acid amount of S. verticillata is higher than in other Salvia 
species. Also, Yumrutas et al. (2011) showed that two varities of S. verticillata displayed strong antioxidant activity and they indicated that two varieties of $S$. verticillata have especially rich in rosmarinic acid and caffeic acid contents. Literature claimed that Salvia is characterized by the rosmarinic acid (Tepe, 2008). Further, Kan, et al. (2007) found that $S$. frigida has the highest rosmarinic acid and caffeic acid contents compare to $S$. candidissima, $S$. virgata and $S$. verticillata. However, the present study found that the caffeic acid content of $S$. frigida is low $(19.71 \pm 1.11 \mu \mathrm{g} / \mathrm{mg})$. In addition, Kan et al. (2007) indicated that $S$. virgata has low rosmarinic acid and caffeic acid contents.

Table 2. The results of flavonoid and phenolic acid contents of Salvia taxa $(\mu \mathrm{g} / \mathrm{mg})$.

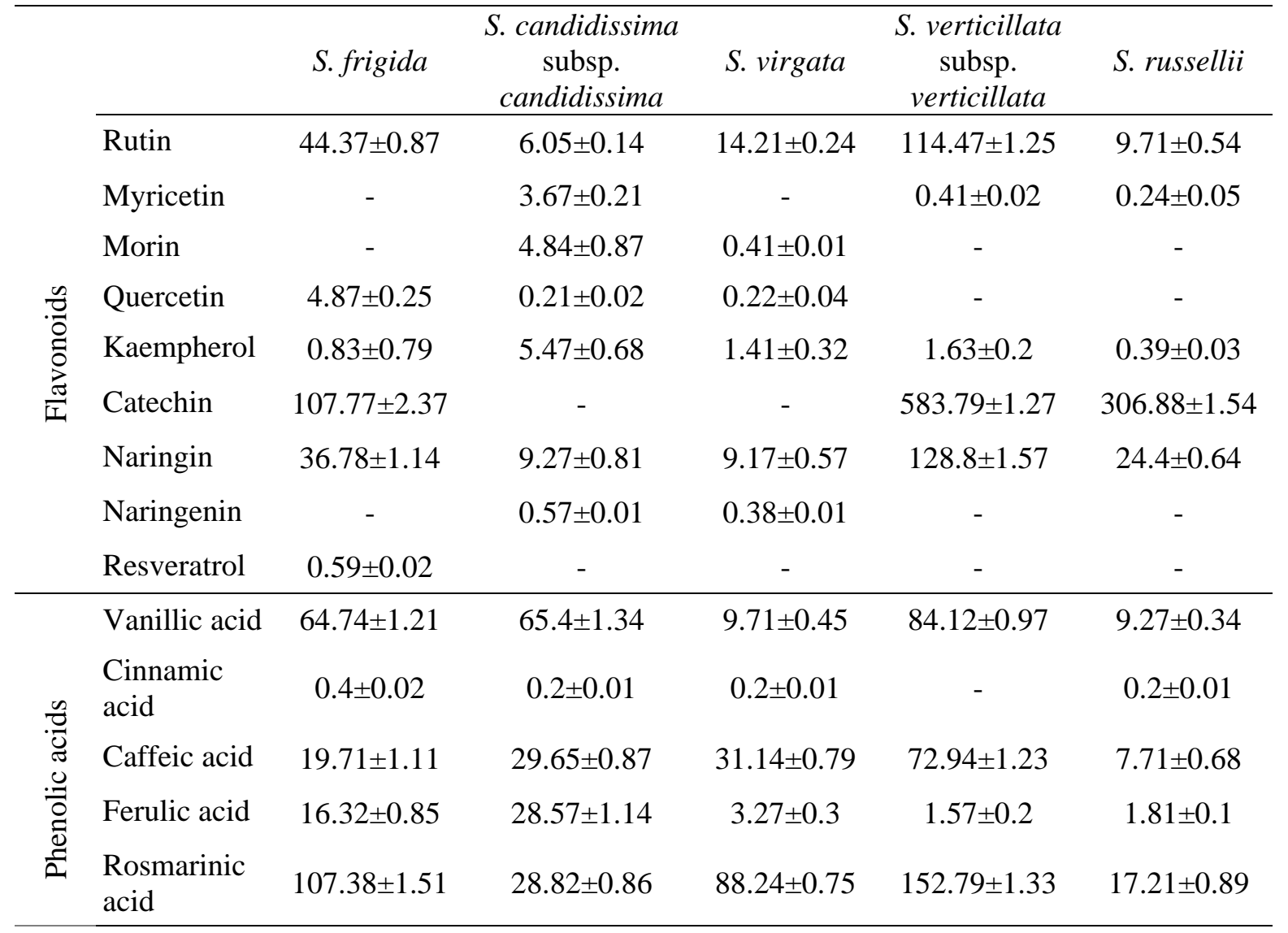

On the other hand, the current study suggested that in general, S. verticillata subsp. verticillata has high DPPH and ABTS radical scavenging activities (Table 3 and Table 4). Similarly, Yumrutas et al. (2011) indicated that two varieties of $S$. verticillata have exhibited the strongest DPPH radical scavenging. The studied taxa have the highest ABTS radical scavenging activity in 150 and $250 \mu \mathrm{L}$ whilst studied taxa except for $(S$. candidissima subsp. candidissima) posses highest DPPH radical scavenging activity in $250 \mu \mathrm{L}$ (Table 3 and Table 4). On the contrary, S. frigida has lowest DPPH radical scavenging capacity in $25 \mu \mathrm{L}$ and 50 $\mu \mathrm{L}$ and $S$. russellii, S. candidissima, S. virgata have the lowest DPPH scavenging activity in some concentrations (Table 3). However, Senol et al. (2010) suggested that $S$. candidissima, $S$. virgata and $S$. russellii have the strongest DPPH radical scavenging activity whilst Orhan et al., (2007) showed that $S$. verticillata has DPPH scavenging capacity are between $68.91 \pm 0.21 \%$ and $81.1 \pm 2.48 \%$. Also, another study by done Orhan et al. (2013) demonstrated that S. frigida and $S$. verticillata have strong DPPH radical scavenging. 
Table 3. The DPPH\% results of extracts of Salvia L. taxa.

\begin{tabular}{lccccc}
\hline Taxa & $25 \mu \mathrm{L}$ & $50 \mu \mathrm{L}$ & $100 \mu \mathrm{L}$ & $150 \mu \mathrm{L}$ & $250 \mu \mathrm{L}$ \\
\hline $\begin{array}{l}\text { S. frigida } \\
\text { S. candidissima subsp. } \\
\text { candidissima }\end{array}$ & $27.22 \pm 0.59$ & $16.8 \pm 0.56$ & $61.7 \pm 1.13$ & $91.9 \pm 1.17$ & $93.9 \pm 1.41$ \\
$\begin{array}{l}\text { S. virgata } \\
\text { S. verticillata } \text { subsp. }\end{array}$ & $82.14 \pm 1.25$ & $44.97 \pm 0.84$ & $13.12 \pm 0.58$ & $29.4 \pm 0.87$ & $52.9 \pm 1.18$ \\
verticillata & $60.11 \pm 1.87$ & $93.78 \pm 1.17$ & $43.04 \pm 0.97$ & $27.8 \pm 0.58$ & $84.1 \pm 1.21$ \\
S. russellii & $14.7 \pm 0.59$ & $97.59 \pm 1.82$ & $96.32 \pm 1.34$ & $36.2 \pm 0.97$ & $92.7 \pm 1.64$ \\
\hline
\end{tabular}

Table 4. The The ABTS\% results of extracts of Salvia L. taxa.

\begin{tabular}{lccccc}
\hline Taxa & $25 \mu \mathrm{L}$ & $50 \mu \mathrm{L}$ & $100 \mu \mathrm{L}$ & $150 \mu \mathrm{L}$ & $250 \mu \mathrm{L}$ \\
\hline $\begin{array}{l}\text { S. frigida } \\
\text { S. candidissima subsp. }\end{array}$ & $53.44 \pm 1.12$ & $95.68 \pm 1.64$ & $99.67 \pm 1.45$ & $98.71 \pm 1.12$ & $98.14 \pm 1.24$ \\
candidissima & $20.34 \pm 0.87$ & $41.20 \pm 1.12$ & $73.62 \pm 1.12$ & $93.96 \pm 1.13$ & $98.81 \pm 1.11$ \\
$\begin{array}{l}\text { S. virgata } \\
\text { S. verticillata subsp. }\end{array}$ & $26.55 \pm 0.98$ & $41.03 \pm 0.91$ & $75.34 \pm 1.24$ & $98.82 \pm 0.84$ & $98.82 \pm 0.97$ \\
verticillata & $88.44 \pm 1.29$ & $98.65 \pm 1.29$ & $98.87 \pm 1.14$ & $98.57 \pm 0.51$ & $98.65 \pm 0.79$ \\
S. russellii & $28.10 \pm 0.78$ & $41.72 \pm 0.86$ & $90.51 \pm 1.57$ & $98.79 \pm 0.84$ & $98.85 \pm 0.91$ \\
\hline
\end{tabular}

Furthermore, it was found that $S$. verticillata subsp. verticillata $(266.66 \pm 0.9 \mu \mathrm{gGAE} / \mathrm{mg})$ has the highest total phenolic content whilst $S$. frigida has the lowest $(76.49 \pm 1.06 \mu \mathrm{gGAE} / \mathrm{mg})$ total phenolic content in the present study (Table 5). Zengin et al. (2018) showed that total phenolic content of $S$. verticillata as $53.52 \pm 1.66 \mathrm{mg} / \mathrm{g}$. Also, Tosun et al. (2009) determined the total phenolic content of $S$. verticillata, $S$. virgata and $S$. candidissima as $167.1 \mathrm{mg} / \mathrm{g}, 101.2$ $\mathrm{mg} / \mathrm{g}$ and $100.3 \mathrm{mg} / \mathrm{g}$, respectively whilst Kupeli Akkol et al. (2008) found that S. virgata has $133.8 \mathrm{mg} / \mathrm{g}$ total phenolic content. Literature showed that there is a correlation between phenolics and antioxidant activities of Salvia species (Tosun et al., 2009). This study showed that there is a strong correlation between total phenolics and DPPH $\left(r^{2}: 0.752\right)$ and ABTS $\left(r^{2}\right.$ : $0.764)$ while there is moderate correlation between total phenolics and metal chelating $\left(\mathrm{r}^{2}\right.$ : $0.305)$.

Table 5. The lipid peroxidation $(\mathrm{mg} / \mathrm{kg}$ ), total phenolic amounts $(\mu \mathrm{gGAE} / \mathrm{mg})$ and metal chelating activities (\%) of Salvia L. taxa.

\begin{tabular}{lccc}
\hline \multicolumn{1}{c}{ Taxa } & Lipid peroxidation & Total Phenolic & Metal Chelating \\
\hline $\begin{array}{l}\text { S. frigida } \\
\text { S. } \text { candidissima }\end{array}$ & $19.95 \pm 0.82$ & $160.87 \pm 1.72$ & $77.84 \pm 0.95$ \\
subsp. candidissima & $23.36 \pm 0.51$ & $76.49 \pm 1.06$ & $80.48 \pm 1.11$ \\
$\begin{array}{l}\text { S. virgata } \\
\text { S. verticillata. subsp. }\end{array}$ & $22.42 \pm 0.78$ & $81.92 \pm 1.01$ & $71.88 \pm 0.86$ \\
verticillata & $20.87 \pm 0.62$ & $266.66 \pm 0.93$ & $45.04 \pm 0.84$ \\
S. russellii & $20.29 \pm 0.67$ & $94.73 \pm 1.24$ & $53.51 \pm 0.59$ \\
\hline
\end{tabular}


Table 6. The disc diffusion assay results of the antimicrobial susceptibility tests for growing reference microorganisms.

\begin{tabular}{lcccccc}
\hline \multirow{2}{*}{$\begin{array}{l}\text { Reference } \\
\text { Microorganisms }\end{array}$} & $S f$ & $S c$ & $S v$ & $S v e r$ & $S r$ & Reference \\
\hline E coli & $11.00 \pm 0.0^{\mathrm{d}}$ & - & - & - & - & $11.66 \pm 0.3^{*}$ \\
S. aureus & $11.00 \pm 0.0^{\mathrm{d}}$ & $8.33 \pm 0.3^{\mathrm{c}}$ & $13.33 . \pm 0.3^{\mathrm{d}}$ & $13.33 \pm 0.3^{\mathrm{cd}}$ & $13.33 \pm 0.3^{\mathrm{cd}}$ & $9.66 \pm 0.3^{*}$ \\
K. pneumoniae & $8.33 \pm 0.3^{\mathrm{c}}$ & $11.33 \pm 0.3^{\mathrm{d}}$ & $13.33 \pm 0.3^{\mathrm{d}}$ & $11.33 \pm 0.3^{\mathrm{d}}$ & $8.33 \pm 0.3^{\mathrm{c}}$ & $11.66 \pm 0.3^{*}$ \\
B. megaterium & $14.33 \pm 0.3^{\mathrm{cd}}$ & $8.33 \pm 0.3^{\mathrm{c}}$ & $8.33 \pm 0.3^{\mathrm{c}}$ & $17.33 \pm 0.3^{\mathrm{cd}}$ & $13.33 \pm 0.3^{\mathrm{cd}}$ & $11.66 \pm 0.3^{*}$ \\
C. albicans & $10.66 \pm 0.33^{\mathrm{d}}$ & $14.33 \pm 0.3^{\mathrm{cd}}$ & - & $16.66 \pm 0.33^{\mathrm{cd}}$ & $11.33 \pm 0.3^{d}$ & $11.66 \pm 0.3^{* *}$ \\
C. glabrata & - & $11.33 \pm 0.3^{\mathrm{d}}$ & - & - & - & $8.66 \pm 0.3^{* *}$ \\
Epidermophyton sp. & - & - & - & - & & $8.33 \pm 0.3^{* *}$ \\
Trichopyton sp. & - & - & - & - & - & $8.33 \pm 0.3^{* *}$ \\
\hline
\end{tabular}

Sf; S. frigida, Sc; S. candidisssima, Sv; S. virgata, Sver: S. verticillata, Sr: S. russellii. PS; positive control; ampicillin sulbactam (*) and micostatin (**) $120 \mu \mathrm{L}$ and $20 \mu \mathrm{g} /$ disc, Interpretation of zone diameters (mm); Zone of diameter $>11 \mathrm{~mm}$ (susceptible; $p<0.0001 ; \mathrm{cd}, p<0.001 ; \mathrm{d})$, resistant $=8-10 \mathrm{c}: p<0.01$, not susceptible $(-)(\mathrm{a}: p>0.05)$.

Besides, the current study showed that $S$. candidissima subsp. candidissima has the highest metal chelating capacity $(80.48 \pm 1.11 \%)$ and $S$. verticillata subsp. verticillata has lowest metal chelating capacity $(45.04 \pm 0.84 \%)$ (Table 5). Senol et al., (2010) found that the methanol extracts of Salvia species including $S$. candidissima, S. virgata and S. russellii have displayed neligible metal chelating action. However, Seker Karatoprak et al. (2016) suggested that $S$. virgata may be able to protect against complexing free iron (II) ions. Moreover, the lipid peroxidation of studied taxa changed from $19.95 \pm 0.82 \mathrm{mg} / \mathrm{kg}$ (S. frigida) to $23.36 \pm 0.51 \mathrm{mg} / \mathrm{kg}$ (S. candidissima subsp. candidissima) in this study (Table 5). Tepe, et al. (2007) indicated that inhibition activity of the linoleic acid of $S$. verticillata subsp. verticillata is $74.4 \pm 1.29 \%$. Also, Jeshvaghani et al. (2015) found that oxidation of lipid peroxidation was blocked by Salvia species including $S$. virgata. Besides, it was indicated that Salvia species mostly great protective role against lipid peroxidation study done by Asadi et al. (2010).

Moreover, the present study demonstrated that phenolic contents of Salvia L. taxa represented different antimicrobial activities (Table 6). It was showed that $S$. verticillata subsp. verticillata represented higher antimicrobial activity against $B$. megaterium, $C$. albicans and $S$. aureus than other studied Salvia taxa. And also, it was found that only $S$. frigida exhibited antimicrobial activity against $E$. coli while only $S$. candidissima subsp. candidissima exhibited antimicrobial activity against $C$. glabrata. On the other hand, it was determined that studied Salvia taxa don't show antimicrobial activity against Epidermophyton sp. and Trichopyton sp. (Table 6). It was reported that Salvia taxa have potent antimicrobial activity study by done Bayar and Genc (2016). They showed that the methanolic extracts of $S$. candidisssima have significant antifungal capacity (Bayar \& Genc, 2018). In another study by done Akin et al. (2010). S. russellii is effective against micororganisms. And also, Kunduhoglu et al. (2011) suggested that $S$. verticillata exhibited antimicrobial activity.

\section{CONCLUSION}

The present study demonstrated that the catechin amounts of S. frigida, S. verticillata subsp. verticillata and $S$. russellii are high whilst the the rutin and naringin content of $S$. verticillata subsp. verticillata are high. Also, the current study showed that $S$. frigida and $S$. verticillata subsp. verticillata have high rosmarinic acid and $S$. frigida $(64.74 \pm 1.21 \mu \mathrm{g} / \mathrm{mg}), S$. candidissima $(65.4 \pm 1.34 \mu \mathrm{g} / \mathrm{mg})$ and $S$. verticillata subsp. verticillata $(84.12 \pm 0.97 \mu \mathrm{g} / \mathrm{mg})$ have high vanilic acid content. On the other hand, it was found that Salvia taxa have high ABTS (in 100,150 and $250 \mu \mathrm{L}$ ) and DPPH (in $250 \mu \mathrm{L}$ ) except for $S$. candidissima subsp. candidissima) radical scavenging activities. Moreover, it was demostrated that S. frigida and Salvia 
verticillata subsp. verticillata have high total phenolic content. And also, Salvia taxa represented antimicrobial activity.

\section{Acknowledgements}

Firat University Scientific Research Unit provided a financial support to this study by project number FUBAP 2041. We greatly acknowledge Firat University Scientific Research Unit. And also, some data of the study is presented and the study is placed as National Botanical Science Congress Abstract Book (25-28 October 2014, pp. 87-88).

\section{Declaration of Conflicting Interests and Ethics}

The authors declare no conflict of interest. This research study complies with research publishing ethics. The scientific and legal responsibility for manuscripts published in IJSM belongs to the author(s).

\section{Authorship contribution statement}

İran Emre: The methodology (except for antimicrobial activity), the statistical analysis of results (except for antimicrobial results), the writing of original draft. Murat Kursat: The collection of plant materials, the nomenclature of plants, the methodology (except for antimicrobial activity). Sevda Kirbag: The methodology, the writing of the antimicrobial results. Pinar Erecevit: The methodology (antimicrobial activity), the writing of the antimicrobial results. Mustafa Yunus Emre: The methodology (except for antimicrobial activity). Okkes Yilmaz: The methodology (except for antimicrobial activity; Gas Chromatography and HPLC analysis). Semsettin Civelek: The nomenclature of plants.

\section{Orcid}

İran Emre https://orcid.org/0000-0003-0591-3397

Murat Kursat ${ }^{(D)}$ https://orcid.org/0000-0002-0861-4213

Sevda Kirbag(D) https://orcid.org/0000-0002-4337-8236

Pinar Erecevit (iD https://orcid.org/0000-0003-2389-0694

Mustafa Yunus Emre ${ }^{(D)}$ https://orcid.org/0000-0001-6602-8872

Okkes Yilmaz (iD) https://orcid.org/0000-0002-8276-4498

Semsettin Civelek (iD) https://orcid.org/0000-0002-6868-4125

\section{REFERENCES}

Akin, M., Oguz, D., \& Saracoglu, H.T. (2010). Antibacterial effects of some plant extracts from Labiatae (Lamiaceae) growing naturally around Şırnak-Silopi, Turkey. International Journal of Pharmaceutical and Applied Sciences, 1 (1), 4-47.

Alcantaraa, M.A., Polaria, I.L.B., Meirelesa, B.R.L.A., Limab, A.E.A., Junior, J.C.S., Vieiraa, E.A., Santos, N.A., Tribuzy, A.M. \& Cordeiro, M.C. (2019). Effect of the solvent composition on the profile of phenolic compounds extracted from chia seeds. Food Chemistry, 275, 489-496. https://doi.org/10.1016/j.foodchem.2018.09.133

Asadi, S., Ahmadiani, A., Esmaeili, M.A., Sonboli, A., Ansari, N., \& Khodagholi, F. (2010). In vitro antioxidant activities and an investigation of neuroprotection by six Salvia species from Iran: A comparative study. Food and Chemical Toxicology, 48, 1341-1349. https://doi.org/10.1016/j.fct.2010.02.035

Bayar, Y., \& Genc, N. (2016). The determination of total phenolic and antioxidant capacity of Salvia verticillata subsp. amasiaca. Journal of Nevsehir Science and Technology, 5(2), 158-166. (in Turkish). http://dx.doi.org/10.17100/nevbiltek.284739

Bayar, Y., \& Genc, N. (2018). Determination of the chemical components, antioxidant and antifungal activities of essential oil and plant extract of Salvia candidissima Vahl., 
Mediterranean Agricultural Sciences, 31(2), 93-99.

https://doi.org/10.29136/mediterranean.362163

Cetin, H., Cinbilgel, I., Yanikoglu, A., \& Gokceoglu, M. (2006). Larvicidal activity of some Labiatae (Lamiaceae) plant extracts from Turkey. Phytotherapy Research, 20, 1088 1090. https://doi.org/10.1002/ptr.2004

Collins, C.M., \& Lyne, P.M. (1987). Microbiological methods buttermorths \& co (Publishers) Ltd. London $450 \mathrm{pp}$.

Dinis, T.C.P., Madeira, V.M.C., \& Almeida, M.L.M. (1994). Action of phenolic derivates (acetoaminophen, salycilate and 5-aminosalycilate) as inhibitors of membrane lipid peroxidation and as peroxyl radical scavengers. Archives Biochemistry Biophysics, 315, 161-169. https://doi.org/10.1006/abbi.1994.1485

Dent, M., Kovacevic, D.B., Bosiljkov, T., \& Dragovic-Uzelac, V. (2017). Polyphenolic composition and antioxidant capacity of indigenous wild dalmatian sage (Salvia officinalis L.). Croatica Chemica Acta, 90(3), 451-459. https://doi.org/10.5562/cca3231

Dincer, C., Topuz, A., Sahin-Nadeem, H., Ozdemir, K.S., Cam, I.B., Tontul, I., Gokturk, R.S., \& Ay, S.T. (2012). A comparative study on phenolic composition, antioxidant activity and essential oil content of wild and cultivated sage (Salvia fructicosa Miller) as influenced by storage. Industrial Crops and Products, 39, 170-176. https://doi.org/10.1016/j.indcrop.2012.02.032

Dorman, H.J., Bachmayer, O., Kosar, M., \& Hiltunen, R. (2004). Antioxidant properties of aqueous extracts from selected Lamiaceae species grown in Turkey. Journal of Agricultural and Food Chemistry, 52, 762-770. https://doi.org/10.1021/jf034908v

Fotovvat, M., Radjabian \& T., Saboora, A. (2019). HPLC fingerprint of important phenolic compounds in some Salvia L. species from Iran. Records of Natural Products, 1, 37-49. http://doi.org/10.25135/rnp.72.18.02.228

Gregorczyk-Karolak, I., \& Kiss, A.K. (2018). Determination of the phenolic profile and antioxidant properties of Salvia viridis L. shoots: A comparison of aqueous and hydroethanolic extracts. Molecules, 23, 1468, 1-18. https://doi.org/10.3390/molecules23 061468

Hamrouni-Sellami, I., Rahali, F.Z., Rebey, I.B., Bourgou, S., Limam, F., \& Marzouk, B. (2013). Total phenolics, flavonoids, and antioxidant activity of sage (Salvia officinalis L.) plants as affected by different drying methods. Food Bioprocess Technology, 6, 806-817. https://doi.org/10.1007/s11947-012-0877-7

Hossain, M.B., Barry-Ryan, C., Martin-Diana, A.B., \& Brunton, N.P. (2010). Effect of drying method on the antioxidant capacity of six Lamiaceae herbs. Food Chemistry, 123, 85-91. https://doi.org/10.1016/j.foodchem.2010.04.003

Jasicka-Misiak, I., Poliwoda, A., Petecka, M., Buslovych, O., Shlyapnikov, V.A., \& Wieczorek, P.P. (2018). Antioxidant phenolic compounds in Salvia officinalis L. and Salvia sclarea L. Ecological Chemistry Engeneering Society, 25(1), 133-142. https://doi.org/10.1515/eces-2018-0009

Jeshvaghani, Z.A., Rahimmalek, M., Talebi, M., \& Goli, S.A.H. (2015). Comparison of total phenolic content and antioxidant activity in different Salvia species using three model systems. Industrial Crops and Products, 77, 409-414. https://doi.org/10.1016/j.indcrop.2015.09.005

Kahraman, A., Celep, F., \& Dogan, M. (2009). A new record for the flora of Turkey: Salvia viscosa Jacq. (Labiatae). Turkish Journal of Botany, 33, 53-55. https://doi.org/10.3906/bot-0806-3

Kahraman, A., Büyükkartal, H.N., \& Doğan, M. (2018). Pericarp ultrastructure of Salvia section hemisphace (Mentheae; Nepetoideae; Lamiaceae). Commagene Journal of Biology, 2(1), 1-7. https://doi.org/10.31594/commagene.397144 
Kan, Y., Gokbulut, A., Kartal, M., Konuklugil, B., \& Yilmaz, G. (2007). Development and validation of a LC method for the analysis of phenolic acids in Turkish Salvia species. Chromatographia Supplement, 66, 147-152. https://doi.org/10.1365/s10337-007-0278-7

Katanic-Stankovica, J.S., Sreckovic, N., Mišićc, N., Gašićc, U., Imbimboe, P., Montie, D.M., \& Mihaliovic, V. (2020). Bioactivity, biocompatibility and phytochemical assessment of lilac sage, Salvia verticillata L. (Lamiaceae)- A plant rich in rosmarinic acid. Industiral Crops \& Products, 143, 1-11. https://doi.org/10.1016/j.indcrop.2019.111932

Keser, S., Demir, E., \& Yilmaz, O. (2014). Phytochemicals and antioxidant activity of the almond kernel (Prunus dulcis Mill.) from Turkey. Journal of Chemical Society of Pakistan, 36 (3), 534-541.

Khaled-Khodjaa, N., Boulekbache-Makhlouf, L., \& Madani, K. (2014). Phytochemical screening of antioxidant and antibacterial activities of some Lamiaceae. Industrial Crops and Products, 61. https://doi.org/10.1016/j.indcrop.2014.06.037

Kupeli Akkol, E., Goger, F., Kosar, M., \& Baser, K.H.C. (2008). Phenolic composition and biological activities of Salvia halophila and Salvia virgata from Turkey. Food Chemistry, 108, 942-949. https://doi.org/10.1016/j.foodchem.2007.11.071

Kunduhoglu, B., Kurkcuoglu, M., Duru, M.E., \& Baser K.H.C. (2011). Antimicrobial and anticholinesterase activities of the essential oils isolated from Salvia dicroantha Stapf., Salvia verticillata $\mathrm{L}$. subsp. amasiaca (Freyn and Bornm.) Bornm. and Salvia wiedemannii Boiss. Journal of Medicinal Plants Research, 5(29), 6484-6490. https://doi.org/10.5897/JMPR11.220.

Liyana-Pathiranan, C.M. \& Shahidi F. (2005). Antioxidant activity of commercial soft and hard wheat (Triticum aestivum L.) as affected by gastric $\mathrm{pH}$ conditions. Journal of Agricultural and Food Chemistry, 53, 2433-2440. https://doi.org/10.1021/jf049320i

Lopresti, A.L. (2017). Salvia (sage): A review of its potential cognitive-enhancing and protective effects. Drugs $R \& D, 17,53-64$. https://doi.org/10.1007/s40268-016-0157-5x

Orhan, I., Kartal, M., Naz, O., Ejaz, A., Yilmaz, G., Kan, Y., Konuklugil, B., Sener, B., \& Choudhary M.I. (2007). Antioxidant and anticholinesterase evaluation of selected Turkish Salvia species. Food Chemistry, 103, 1247-1254. https://doi.org/10.1016/j.foodchem.20 06.10.030

Orhan, I.E., Senol, F.S., Ercetin, T., Kahraman, A., Celep, F., Akaydin, G., Sener, B., \& Dogan, M. (2013). Assessment of anticholinesterase and antioxidant properties of selected sage (Salvia) species with their total phenol and flavonoid contents. Industrial Crops and Products, 41, 21-30. https://doi.org/10.1016/j.indcrop.2012.04.002

Ree, R., Pellegrini, N., Proteggente, A., Pannala, A., Yang, M., \& Rice-Evans, C. (1999). Antioxidant activity applying an improved ABTS radical cation decolorization assay. Free Radical Biology and Medicine, 26, 1231-1237. https://doi.org/10.1016/S08915849(98)00315-3

Robya, H.H., Sarhana, M.A., Selima, K.A., \& Khalel, K.I. (2013). Evaluation of antioxidant activity, total phenols and phenolic compounds in thyme (Thymus vulgaris L.), sage (Salvia officinalis L.), and marjoram (Origanum majorana L.) extracts. Industrial Crops and Products, 43, 827-831. https://doi.org/10.1016/j.indcrop.2012.08.029

Seker Karatoprak, G., Ilgun, S., \& Koşar M. (2016). Antioxidant properties and phenolic composition of Salvia virgata Jacq. Turkish Journal of Pharmaceutical Sciences, 13(2), 201-212.

Senol, F.S., Orhan, I., Celep, F., Kahraman, A., Dogan, M., Yilmaz, G., \& Sener, B. (2010). Survey of 55 Turkish Salvia taxa for their acetylcholinesterase inhibitory and antioxidant activities. Food Chemistry, 120, 34-43. https://doi.org/10.1016/j.foodchem.2009.09.066

Shekarchi, M., Hajimehdipoor, H., Saeidnia, S., Gohari, A.R. \& Hamedani, M.P. (2012). Comparative study of rosmarinic acid content in some plants of Labiatae family. 
Pharmacognosy Magazine, 8, 37-41. http://www.phcog.com/text.asp?2012/8/29/37/933 16

Shimoi, K., Masuda, S., Furugoru, M., Esaki, S., \& Kinae, N. (1994). Radioprotective effect of antioxidative flavonoids in X-ray irradiated mice. Carcinogenesis, 15, 2669-2672. https://doi.org/10.1093/carcin/15.11.2669

Singleton, V.L., Orthofer, R., \& Lamuela-Raventos, R.M. (1999). Analysis of total phenols and other oxidation substrates and antioxidants by means of folin-ciocalteu reagent. Methods in Enzymology, 299, 152-178. https://doi.org/10.1016/S0076-6879(99)99017-1

Skendi, A., Irakli, M., \& Chatzopoulou, P. (2017). Analysis of phenolic compounds in Greek plants of Lamiaceae family by HPLC. Journal of Applied Research on Medicinal and Aromatic Plants, 62, 696. https://doi.org/10.1016/j.jarmap.2017.02.001

Skotti, E., Anastasaki, E., Kanello, G., Polissiou, M., \& Tarantilis, P.A. (2014). Total phenolic content, antioxidant activity and toxicity of aqueous extracts from selected Greek medicinal and aromatic plants. Industrial Crops and Products, 53, 46-54. https://doi.org/10.1016/j.indcrop.2013.12.013

Tepe B, Eminagaoglu, E., Akpulat, H.A., \& Aydin, E. (2007). Antioxidant potentials and rosmarinic acid levels of the methanolic extracts of Salvia verticillata (L.) subsp. verticillata and S. verticillata (L.) subsp. amasiaca (Freyn \& Bornm.) Bornm. Food Chemistry, 100, 985-989. https://doi.org/10.1016/j.foodchem.2005.10.062

Tepe, B. (2008). Antioxidant potentials and rosmarinic acid levels of the methanolic extracts of Salvia virgata (Jacq), Salvia staminea (Montbret \& Aucher ex Bentham) and Salvia verbenaca (L.) from Turkey. Bioresource Technology, 99, 1584-1588. https://doi.org/10.1016/j.biortech.2007.04.008

Tosun, M., Ercisli, S., Sengul, M., Ozer, H., Polat, T., \& Ozturk, E. (2009). Antioxidant properties and total phenolic content of eight Salvia species from Turkey. Biological Research, 42, 175-181. http://dx.doi.org/10.4067/S0716-97602009000200005

Vergine, M., Nicoli, F., Negro, C., Luvisi, A., Nutricati, E., Accogli, R.A., Sabella E., \& Miceli, A. (2019). Phytochemical profiles and antioxidant activity of Salvia species from southern Italy. Records of Natural Products, 13(3), 205-215. http://doi.org/10.25135/rnp.96.18.07.119

Yumrutas, O., Sokmen, A., \& Ozturk, N. (2011). Determination of in vitro antioxidant activities and phenolic compounds of different extracts of Salvia verticillata ssp. verticillata and spp. amasiaca from Turkey's flora. Journal of Applied Pharmaceutical Science, 01 (10), 43-46.

Zengin, G., Llorent-Martinez, E., Fernandez-de Cordova, M.L., Bahadori, M.B., Mocan, A., Locatelli, M., \& Aktumsek A. (2018). Chemical composition and biological activities of extracts from three Salvia species: S. blepharochlaena, S. euphratica var. leiocalycina, and S. verticillata subsp. amasiaca. Industrial Crops \& Products, 111, 11-21. https://doi.org/10.1016/j.indcrop.2017.09.065

Zu, Y.G., Li, C.Y., Fu, Y.J., \& Zhao, C.J. (2006). Simultaneous determination of catechin, rutin, quercetin kaempferol and isorhamnetin in the extract of sea buckthorn (Hippophae rhamnoides L.) leaves by RP-HPLC with DAD. Journal of Pharmaceutical and Biomedical Analysis, 41, 714-719. https://doi.org/10.1016/j.jpba.2005.04.052 